\title{
Characterization of biodegradable film based on zein and oleic acid added with nanocarbonate
}

\author{
Caracterização de filme biodegradável a base de zeína \\ e ácido oléico adicionado de nanocarbonato
}

\author{
Wanessa Ximenes Ribeiro ${ }^{I^{*}}$ José Francisco Lopes Filho \\ Monica Souza Cortes ${ }^{I}$ Carmen Cecília Tadini ${ }^{I I}$
}

\begin{abstract}
Zein oleic acid films added with 1, 2 and 3\% (w/w) of nanocarbonate and $30 \%$ glycerol as plasticizer, were produced and evaluated according to their structure and functional properties. Structural characteristics were analyzed by optical and scanning electron microscopy (SEM). Water solubility and mechanical properties were determined according to ASTM methods. The increase of nanocarbonate concentration increased water solubility and influenced the color and mechanical properties. Optical and SEM of film samples added with nanocarbonate, shown low amount of pores and great fat globules size.
\end{abstract}

Key words: zein, biodegradable packaging, nanocarbonate.

\section{RESUMO}

Filmes a base de zeína e ácido oleico adicionados com 1,2 e $3 \%$ de nanocarbonato e 30\% de glicerol como plasticizante foram produzidos e avaliados quanto sua estrutura e propriedades funcionais. Caracteristicas estruturais foram analisadas por meio de microscopia ótica (MO) e eletrônica de varredura (MEV) e solubilidade em água e propriedades mecânicas segundo métodos da ASTM. O aumento na concentração de nanocarbonato, aumentou a solubilidade em água e influenciou na cor e propriedades mecânicas. As análises de $\mathrm{MO}$ e MEV do filme adicionado com nanocarbonato mostraram pouca presença de poros e glóbulos de gordura de maior tamanho quando comparado com o filme controle.

Palavras-chave: zeína, embalagens biodegradáveis, nanocarbonato.

\section{INTRODUCTION}

The quality of a food product is directly dependent of its packing which protects it until the final destination, the customer (VILLADIEGO et al., 2005). The packages are often associated with environmental pollution problems since it has been difficult, in practice, to control their proper disposal and/or recycle according to specific programs (MAGALHÃES, 2001). As legal regulations and public concern put pressure over food industries, there is a technical race in order to develop materials with dual properties to satisfy packaging purposes, while is environmentally acceptable. Biodegradability is the most desired individual characteristic for packages today, for all kinds of industries. Several materials are under intense research in order to obtain biodegradable packaging, such as starch, zein, cellulose, among others. (FELLOWS, 2006). Zein is the main corn protein and has been extensively studied because of its excellent film forming abilities. It is alcohol soluble, produces films with an efficient enough barrier against moisture and has been used commercially as degradable film for food packages (VILLADIEGO, 2005; TAVARES, 2010). However, zein based film is fragile, requiring plasticizer as glycerol and other components to improve its functional properties. Additives such as nanoparticles, can be used to improve the mechanical and barrier properties of zein films without being hazardous to both environment and human (GHANBARZADEH, 2007; MALI, GROSSMANN, YAMASHITA; 2010). On account of differentiated properties that nanoparticles exhibit, it is possible to obtain materials with superior characteristics when compared to composites made with microparticulate materials. (ASSIS et al., 2012). The objectives of this study were to produce and determine

\footnotetext{
'Departamento de Engenharia e Tecnologia de Alimentos, Universidade Estadual Paulista "Júlio de Mesquita Filho" (UNESP), 15054-000,

São José do Rio Preto, SP, Brasil. E-mail: wa_ribeiro@yahoo.com.br. *Corresponding author.

IUniversidade de São Paulo, São Paulo, SP, Brasil. 
structural characteristics and functional properties of zein-oleic acid films added with different concentrations of calcium nanocarbonate $\left(\mathrm{CaCO}_{3}\right)$, in order to evaluate its feasibility for uses as food packing.

\section{MATERIAL AND METHODS}

Materials

Corn-zein was obtained from Sigma-Aldrich. Analytical grade glycerol, oleic acid and ethanol (99.5 $\%$ ) were supplied by Araçaprolab (Araçatuba, Brazil). Sucrose ester off fatty acids was used as emulsifier, specific for oil/water emulsion, in order to incorporate the oleic acid into the films (commercial name: SP70, Sisterna, Brazil) (SOUZA, 2011). Calcium nanocarbonate were obtained as commercial name of NPCC-201.

Film composition and preparation

To prepare films with $20 \mathrm{~g}$ of zein it was added to $100 \mathrm{~mL}$ of ethanol at $95 \%(\mathrm{v} / \mathrm{v})$. Mixtures were mechanically stirred at $65 \pm 0.5^{\circ} \mathrm{C}$ for $5 \mathrm{~min}$, then added with $70 \mathrm{~g}$ of oleic acid, $0.875 \mathrm{~g}$ of emulsifier, $30 \mathrm{~g}$ of glycerol and nanocarbonate at 1,2 or $3 \%$, related to $100 \mathrm{~g}$ of zein. Stirring was kept for another $10 \mathrm{~min}$ and then, according to the casting technique, for each formulation, $6 \mathrm{~g}$ of filmogenic solution was poured onto circular plates $\left(43.96 \mathrm{~cm}^{2}\right.$ of area) of polytetrafluoroethylene (Teflon ${ }^{\circledR}$ ) to obtain a constant thickness. After drying, all films were placed in a controlled relative humidity of $75 \%$ and at ambient temperature of $20 \pm 2{ }^{\circ} \mathrm{C}$ and stored for prior analyses (KECHICHIAN, 2010; ARENAS, 2012; SOUZA, 2011).

Water solubility

Film water solubility was defined as the content of dried matter solubilized after $24 \mathrm{~h}$ of immersion in water. The film was cut into $2 \mathrm{~cm}$ diameter disk and dried in an oven at $105 \pm 2^{\circ} \mathrm{C}$ for $24 \mathrm{~h}$, weighed (initial weight, wi) and immersed into $50 \mathrm{~mL}$ distilled water at $27 \pm 2^{\circ} \mathrm{C}$ for $24 \mathrm{~h}$ under agitation in an orbital shaker MA-410 (Marconi, Brazil) at 76rpm. After 24h of immersion, disks were taken out and dried (final weight, wf) at the same conditions stated before, in order to determine the weight of dried matter that was not solubilized in water. Three replicates of each film were tested and water solubility was calculated according to Equation 1 (PENA-SERNA \& LOPES-FILHO, 2013).

Optical Microscopy

Optical microscopy was carried out in order to determine superficial film homogeneity. The film was cut in $1 \mathrm{~cm}^{2}$ and stained with Xylidine Ponceau solution for $30 \mathrm{~min}$, then washed in a bath of acetic acid $2.5 \%$ for $10 \mathrm{~min}$ and finally washed in a distilled water bath for $10 \mathrm{~min}$. The stained film was placed on a glass microscope slide and dried in an oven for $24 \mathrm{~h}$ at $37^{\circ} \mathrm{C}$. The dried stained film was fixed with Canada balsam and covered with cover glass slide. The sample assembly was dried at room conditions for $24 \mathrm{~h}$ and then analyzed with an optical microscope Olympus BX 60, equipped with an image capture system Olympus DP 71, using a magnification of 10x.

Scanning electron microscopy (SEM)

The surface microstructure of the films was evaluated by Scanning Electron Microscopy (SEM). The sequence for the preparation of the specimen includes the aluminum mounting brackets (stubs) and metalizing (sputtering) following GHANBARZADEH et al. (2007), where samples of the films were fixed on stubs with $12 \mathrm{~mm}$ of diameter with double-sided conductive carbon tape. The samples were metalized with platinum for approximately 60 s and then observed in a scanning electron microscope (FEI Quanta 600FEG) at 10kV.

\section{Mechanical properties}

The tensile properties were obtained using a TA.TX2i Stable Micro Systems texture analyzer (SurreyEngland) in accordance with ASTM D-882-91 (1996). Five sample strips $(25 \times 130 \mathrm{~mm})$ of each formulation were cut and clamped between tensile grips. Force $(\mathrm{N})$ and deformation $(\mathrm{mm})$ were recorded during extension of $0.8 \mathrm{~mm} \mathrm{~min}^{-1}$ and with an initial distance between the grips of $10 \mathrm{~mm}$. The parameters determined were: tensile stress (MPa) and strain at break (\%).

Color

The color of the samples was measured in a spectrum wave between 400-700nm with nominal position UV filter, with viewing area of one square inch in total transmittance mode that focuses a beam of normal light to the film surface. This transmitted light was observed at the opposite side of the device sensor, which measures the intensity of wave lengths. This means that the color was obtained from measurement values for the transmitted light.

\section{Statistical analysis}

Statistical analysis was performed with software Minitab 16. The evaluated factors were nanocarbonate concentrations and the response variables water solubility, water vapor permeability, optical microcopy and scanning electron microscopy. Analysis of variance and Tukey Test were performed to detect significant differences in the properties of the films. The significance level used was 0.05 . 


\section{RESULTS AND DISCUSSION}

\section{Water solubility}

Standard film had the lowest water solubility, therefore being less hydrophilic because of the greater intermolecular force between proteins matrix and other components. Similar result was found by PENA-SERNA \& LOPES-FILHO (2013) where higher concentrations of ethanol showed films with denser structure and less water solubility. Samples with $2 \%$ and $3 \%$ of nanocarbonate presented features visually less homogeneous (dispersed particles), which resulted in increased the solubility (Table 1). Thus, this lack of incorporation of the components in the matrix contributed to increase solubility of the sample. BATISTA et al. (2005) observed that the addition of fatty acids in pectin-based films showed a decrease in its solubility. However, no incorporation of the fatty acid in film matrix contributed to the higher exposure of the hydrocolloid matrix, promoting the solubilization of the film. All samples studied were intact, after 24 hours, immersioned in water, indicating that the protein matrix remained intact.

\section{Scanning electrical microscopy (SEM)}

The SEM micrographs of $0,1,2$ and 3 (Figure 1) showed the surface morphology of the zein films without addition of nanocarbonate and with 1,2 and $3 \%$ of nanocarbonate, respectively. MONTERREYQUINTERO; SOBRAL (2000) and TAVARES (2010) suggested that the black spots observed in the micrographs were micro-bubbles embedded in the matrix or spaces occupied by glycerol previously to the drying process. ALMEIDA et al. (2010) also found black spots in electron micrographs of zein films prepared with oleic acid and glycerol. In order to identify the presence of globular deposits, the authors performed optical microscopy analysis and concluded that observations previously considered as pores in scanning electron microscopy were in fact lipid globules dispersed in the film matrix. Films without addition of nanocarbonate showed black spots (marked with yellow arrows) and those with added nanocarbonate

Table 1 - Water solubility of zein-nanocarbonate films.

\begin{tabular}{ll}
\hline Nanocarbonate (\%) & Water solubility $(\%)$ \\
\hline 0 & $0.4243 \pm 0.1717^{\mathrm{b}}$ \\
1 & $1.5186 \pm 1.1625^{\mathrm{b}}$ \\
2 & $3.8851 \pm 0.1339^{\mathrm{a}}$ \\
3 & $4.0889 \pm 0.3484^{\mathrm{a}}$ \\
\hline
\end{tabular}

${ }^{*}$ Mean \pm standard deviation of each analysis. Different letter indicate a statistically significant difference $(\mathrm{P}<0.05)$. also showed few black points (also identified with yellow arrows). It suggests that nanocarbonate was not fully solubilized in filmogenic solution. From this information and results reported in the literature, it can be concluded that these black spots are in fact micro-pores (microbubbles). The amount of micro-bubbles in the standard film may have interfered with the passage of light, making it more opaque, which was observed previously in the color analysis. For the films with nanocarbonate it was also observed light spots or agglomerates of particles showing less solubilization and/or dispersed nanoparticles in the matrix (marked with red arrows).

\section{Optical Microscopy}

To complement SEM analysis about homogeneity of the film, it was carried out the Optical Microscopy. In this test the proteins are stained red and the fat globules were presented in white tones. The captured images for each sample are shown in figure 2 and the corresponding scale increased the photo $10 \times(500 \mu \mathrm{m})$. The optical micrographs show a lower amount of white points (fat globules) in standard film (without nanocarbonate) than the films with nanocarbonate, confirmed what was found in SEM analysis. The black spots are microbubbles air and not fat globules. As previously mentioned ALMEIDA et al. (2010) performed a comparative analysis of Optical Microscopy in zein films with xanthan gum and concluded that the decrease in size of the fat globules was due to a better homogenization of oil. Unlike observed by

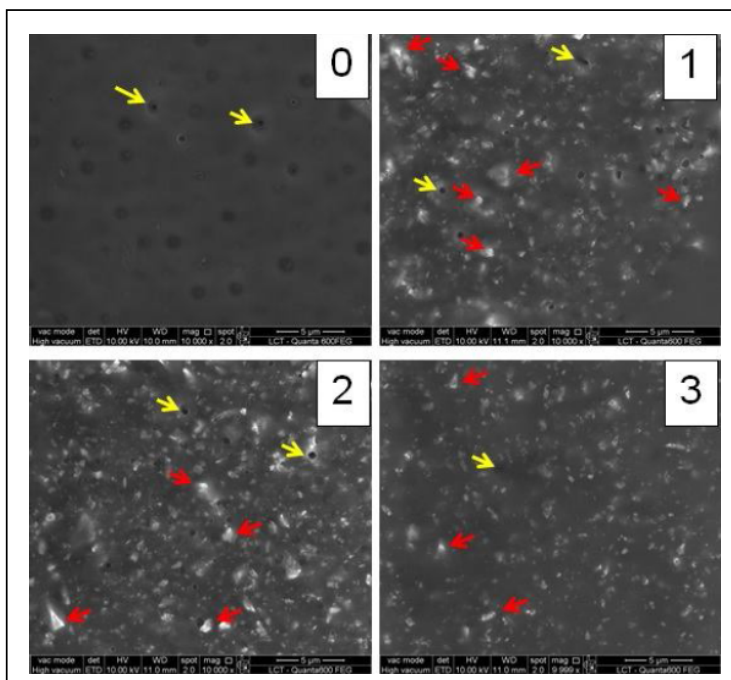

Yellow arrows (black spots - micro-bubbles) and red arrows (light spots - agglomerates of nanocarbonate).

Figure 1 - Eletromicrographs obtained by Scanning Electron Microscopy (SEM) of the films: without nanocarbonate (0), $1 \%$ nanocarbonate (1), $2 \%$ nanocarbonate (2) and $3 \%$ nanocarbonate (3). 
these authors, in the present work it was research large fat globules as nanocarbonate concentration increases. Therefore, films without added nanocarbonate formed a more homogeneous matrix and those with nanocarbonate presented a greater amount of white dots. The weak interaction between zein and the nanocarbonate resulted on glycerol exclusion. For this reason, nanocarbonate films exhibited a greasy perception at touch.

\section{Mechanical properties}

The tensile stress and strain at a break in zein films were affected by nanocarbonate content (Table 2). According to ALMEIDA et al (2010), the larger the diameter of fat globules in the matrix, the lower was the tensile strength and elongation of the film. Comparing the present research with the results found by these authors, in addition to observations of micrographs of the present study, the traction results were confirmed. Values in table 2, showed that films with nanocarbonate presented higher elongation and lower maximum tensile strength. According to MATTA JUNIOR (2009), usually, when film structure becomes less rigid, the strength/tension properties are reduced and the elongation increases. A higher elongation indicates that the film is more flexible. Therefore, according to the results obtained, films become more flexible and elastic because of nanocarbonate addition.

Color

As presented in table 3, nanocarbonate increased significantly $L^{*}$ parameter, indicating brightness, leaving the films lighter. Further studies on the use of higher concentrations of nanocarbonate are suggested. An analogous result can be observed with the values found for $\mathrm{b}^{*}$ (to perceive blue to yellow shades,

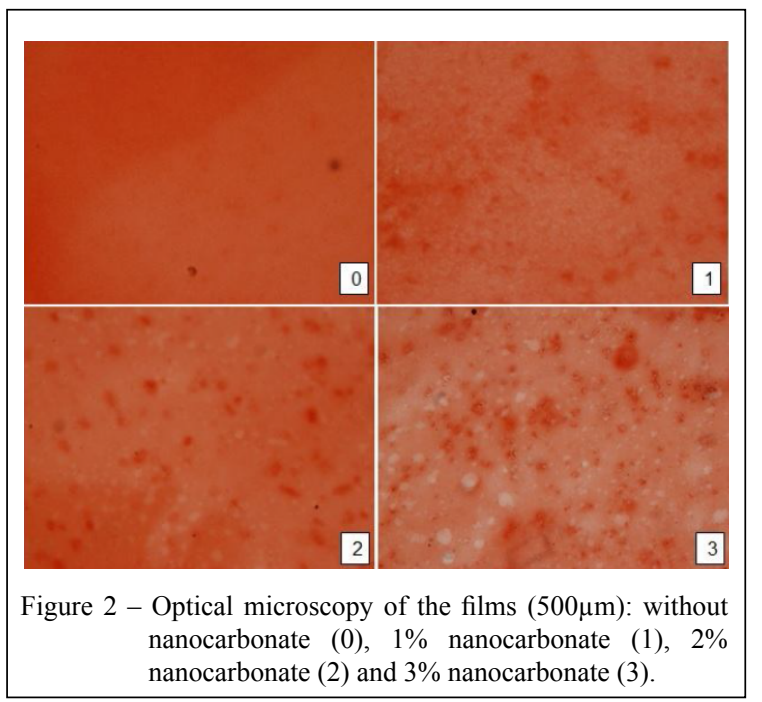

Table 2 - Values of mechanical properties of zein-nanocarbonate films.

\begin{tabular}{lcl}
\hline Nanocarbonate (\%) & $\begin{array}{c}\text { Tensile } \\
\text { stress (MPa) }\end{array}$ & Strain at break (\%) \\
\hline 0 & $1.7583 \pm 0.0479^{\mathrm{a}}$ & $1088.8 \pm 36.2^{\mathrm{b}}$ \\
1 & $1.6731 \pm 0.1647^{\mathrm{b}}$ & $1445.0 \pm 43.2^{\mathrm{a}}$ \\
2 & $1.6656 \pm 0.0677^{\mathrm{b}}$ & $1421.9 \pm 56.6^{\mathrm{a}}$ \\
3 & $1.6545 \pm 0.0565^{\mathrm{b}}$ & $1403.6 \pm 60.9^{\mathrm{a}}$ \\
\hline
\end{tabular}

${ }^{*}$ Mean \pm standard deviation of each analysis. Different letter indicate a statistically significant difference $(\mathrm{P}<0.05)$.

with positive values associated to yellow), where, as nanocarbonate concentration increased, the $b^{*}$ values decreased, indicating a reduction in yellow intensity. Table 4 shows the average values and standard deviations of the color parameter $\mathrm{L}^{*}$ of the films according to nanocarbonate concentration at initial time, after 7, 14 and 30 days of storage. This shows change in color according to time. The films without nanocarbonate and those with $1 \%$ and $2 \%$ had lower values of the $\mathrm{L}^{*}$ after 7 days of storage (the films became slightly darker). The luminosity of the films remained constant. The color remained constant throughout the storage period for films with 3\% nanocarbonate indicating a greater color stability.

\section{CONCLUSION}

The functional and structural properties of zein-oleic acid film were affected by addition of nanocarbonate. Higher concentration of nanocarbonate allowed the improvement of water solubility, color and mechanical properties, making the film more flexible and elastic, as well as more stable related to the color. Nonetheless, there was an increase in the size of fat globules. In general, the results shown the possibilities to use the material with nanocarbonate to pack food

Table 3 - Parameters of color $\mathrm{L}^{*}, \mathrm{a}^{*}$ e $\mathrm{b}^{*}$ of zein-nanocarbonate films.

\begin{tabular}{lcll}
\hline \multirow{2}{*}{ Nanocarbonate $(\%)$} & $\mathrm{L}^{*}$ & $\mathrm{a}^{*}$ & $\mathrm{~b}^{*}$ \\
\hline \multirow{2}{*}{0} & $87.638 \pm$ & $-0.882 \pm$ & $40.682 \pm$ \\
& $1.406^{\mathrm{d}}$ & $0.279^{\mathrm{a}}$ & $3.400^{\mathrm{a}}$ \\
\multirow{2}{*}{1} & $90.509 \pm$ & $-1.356 \pm$ & $35.249 \pm$ \\
& $1.749^{\mathrm{b}}$ & $0.314^{\mathrm{c}}$ & $4.952^{\mathrm{b}}$ \\
2 & $89.675 \pm$ & $-1.078 \pm$ & $35.138 \pm$ \\
& $1.483^{\mathrm{c}}$ & $0.257^{\mathrm{b}}$ & $4.464^{\mathrm{b}}$ \\
3 & $92.057 \pm$ & $-1.370 \pm$ & $28.142 \pm$ \\
& $0.881^{\mathrm{a}}$ & $0.264^{\mathrm{c}}$ & $3.840^{\mathrm{c}}$ \\
\hline
\end{tabular}

${ }^{*}$ Mean \pm standard deviation of each analysis. Different letter indicate a statistically significant difference $(\mathrm{P}<0.05)$.

Ciência Rural, v.45, n.10, out, 2015. 
Table 4 - Parameters of color $\mathrm{L}^{*}$ of zein-nanocarbonate films according to the time.

\begin{tabular}{lcccc}
\hline Time (days) & & & & \\
& & & & \\
& & & \\
& 0 & 1 & 2 & 3 \\
7 & $88.474 \pm 1.255^{\mathrm{a}}$ & $91.682 \pm 1.182^{\mathrm{a}}$ & $90.570 \pm 1.187^{\mathrm{a}}$ & $92.148 \pm 1.009^{\mathrm{a}}$ \\
14 & $86.803 \pm 1.007^{\mathrm{b}}$ & $89.336 \pm 1.410^{\mathrm{b}}$ & $89.008 \pm 1.214^{\mathrm{b}}$ & $91.817 \pm 0.964^{\mathrm{a}}$ \\
30 & $86.026 \pm 0.781^{\mathrm{b}, \mathrm{c}}$ & $89.840 \pm 1.758^{\mathrm{b}}$ & $88.408 \pm 1.706^{\mathrm{b}}$ & $91.945 \pm 0.906^{\mathrm{a}}$ \\
& $85.685 \pm 0.945^{\mathrm{c}}$ & $89.647 \pm 0.918^{\mathrm{b}}$ & $88.195 \pm 1.053^{\mathrm{b}}$ & $91.574 \pm 1.149^{\mathrm{a}}$ \\
\hline
\end{tabular}

${ }^{*}$ Mean \pm standard deviation of each analysis. Different letter indicate a statistically significant difference $(\mathrm{P}<0.05)$.

products, when elasticity, color stability and water solubility are the concern factors.

\section{ACKNOWLEDGMENTS}

This study was supported by a grant from Coordenação de Aperfeiçoamento de Pessoal de Nível Superior (CAPES).

\section{REFERENCES}

ALMEIDA, C.B. et al. Morphological and structural characteristics of zein biofilms with added xanthan gum. Food Technology Biotechnology, Croácia, v. 48, n. 1, p. 19-27, 2010.

ARENAS, A.M.Z. Filme biodegradável à base de fécula de mandioca como potencial indicador de mudança de pH. 2012. 131 f. Dissertação (Mestrado em Engenharia Química) - Escola Politécnica, Universidade de São Paulo, São Paulo, SP.

ASSIS, L.M et al. Características de nanopartículas e potenciais aplicações em alimentos. Jornal Brasileiro de Tecnologia de Alimentos, Campinas, v. 15, n. 2, p. 99-109, 2012.

BATISTA, J.A. et al. Efeito da adição de ácidos graxos em filmes à base de pectina. Ciência e Tecnologia de Alimentos, v. 25, n. 4, p. $781-788,2005$.

FELLOWS, P.J. Tecnologia do processamento de alimentos: princípios e práticas. 2. ed. Trad. F.C. Oliveira et al. Porto Alegre: Artmed, 2006. p. 602.

GHANBARZADEH, B. et al. Effect of plasticizing sugars on water vapor permeability, surface energy and microstructure properties of zein films. Food Science and Technology, v. 40, p.1191-1197, 2007.

KECHICHIAN, V., et al., Natural antimicrobial ingredients incorporated in biodegradable films based on cassava starch, LWT - Food Science and Technology, v. 43, p 1088-1094, 2010.
MAGALHÂES, M. A. Tempo de degradação de materiais descartados no meio ambiente. Jornal do Centro Mineiro para Conservação da Natureza (CMCN). Viçosa-MG, ano 08, n.37, $\mathrm{jan} / \mathrm{fev} / \mathrm{mar} 2001$

MALI, S. et al. Filmes de amido: produção, propriedades e potencial de utilização. Revisões Ciências Agrárias, Londrina, v. 31, n. 1 , p. $137-156,2010$

MATTA JUNIOR, M. D. Caracterização de biofilmes obtidos a partir de amido de ervilha (Pisum sativum) associado à goma xantana e glicerol. 2009. 110 f. Dissertação (Mestrado em Ciência e Tecnologia de Alimentos) - Programa de Pós-graduação em Ciências e Tecnologia de Alimentos, Escola Superior de Agricultura "Luiz de Queiroz", Universidade de São Paulo, Piracicaba, SP.

MONTERREY-QUINTERO, E.S.; SOBRAL, P.J.A. Preparo e caracterização de proteínas miofibrilares de tilápia-do-nilo para elaboração de biofilmes. Pesquisa Agropecuária Brasileira, Brasília, v.35, n. 1, p.179-189, 2000

PENA-SERNA, C.; LOPES-FILHO, J.F. Influence of ethanol and glycerol concentration over functional and structural properties of zein-oleic acid films. Materials Chemistry and Physics, n. 142, p. $580-585,2013$.

SOUZA, A. C. Desenvolvimento de embalagem biodegradável ativa a base de fécula de mandioca e agentes antimicrobianos naturais. 2011. 137 f. Tese (Doutorado em Engenharia Química) - Escola Politécnica, Universidade de São Paulo, São Paulo, SP

TAVARES, L.L. Efeito da adição de argilas modificadas nas propriedades de biofilmes produzidos a base de zeína. 2010 . 74 p. Dissertação (Mestrado) - Universidade Estadual Paulista, Instituto de Biociências, Letras e Ciências Exatas, São José do Rio Preto, 2010

VILLADIEGO, A. M. D. et al. Filmes e revestimentos comestíveis na conservação de produtos alimentícios. Revista CERES, v. 52, n, 300, p. 221-243, 2005. 


\section{ERRATUM}

Artigo "Characterization of biodegradable film based on zein and oleic acid added with nanocarbonate" publicado no fascículo v45n10 de outubro da Ciência Rural páginas 1890-1894, onde se lia:

"Wanessa Ximenes Ribeiro ${ }^{\mathrm{I}}$ José Francisco Lopes Filho ${ }^{\mathrm{I}}$ Monica Souza Cortes"

"Departamento de Engenharia e Tecnologia de Alimentos, Universidade Estadual Paulista "Júlio de Mesquita Filho" (UNESP), 15054-000, São José do Rio Preto, SP, Brasil. E-mail: wa_ribeiro@yahoo.com.br. *Corresponding author."

leia-se:

"Wanessa Ximenes Ribeiro" ${ }^{\mathrm{I} *}$ José Francisco Lopes Filho ${ }^{\mathrm{I}}$ Monica Souza Cortes ${ }^{\mathrm{I}}$ Carmen Cecília Tadini ${ }^{\mathrm{II}}$ "

"Departamento de Engenharia e Tecnologia de Alimentos, Universidade Estadual Paulista "Júlio de Mesquita Filho" (UNESP), 15054-000, São José do Rio Preto, SP, Brasil. E-mail: wa_ribeiro@yahoo.com.br. "Corresponding author.

"Universidade de São Paulo (USP), São Paulo, SP, Brasil."

Para a versão correta, acesse:

http://www.scielo.br/pdf/cr/v45n10/1678-4596-cr-0103_8478cr20141391.pdf 